\title{
Ritual Bakar Tongkang: Refleksi Teologis Bagaimana Manusia Menangkap Tawaran Keselamatan Allah
}

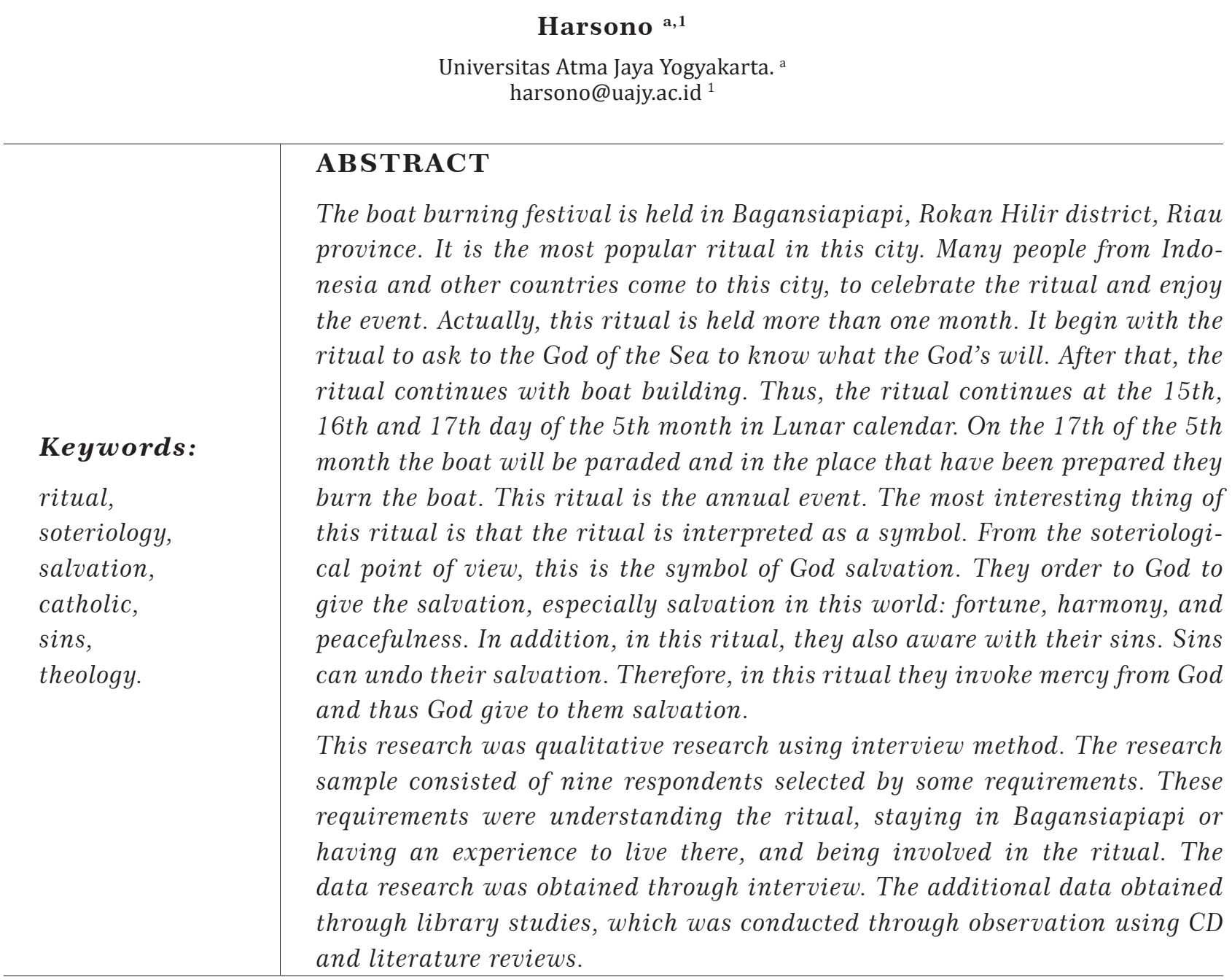

\section{PENDAHULUAN}

Dalam tradisi iman Katolik, karya penyelamatan mula-mula adalah ide atau inisiatif dari Allah. Allah sendirilah yang memberikan tawaran keselamatan itu. Hal ini dapat dilihat dari sejarah panjang karya keselamatan Allah yang mula-mula lewat ber- bagai tanda yang diadakan oleh-Nya sendiri, kemudian lewat perwakilan para nabi, dan sebagai puncaknya adalah ketika Allah mengutus Putera-Nya yang terkasih. Karya keselamatan itu kemudian dilanjutkan kembali oleh Roh Kudus yang merupakan "tangan" lain dari Allah sendiri. 
Keinginan Allah untuk menyelamatkan manusia pada dasarnya adalah melulu karena belas kasih Allah sendiri. ${ }^{1}$ Allah yang sejak awal mula dikenal sebagai penyelamat tetap setia mengerjakan karya keselamatan itu. Bagi Allah, dosa bukanlah suatu halangan untuk mengerjakan karya itu di antara manusia. Kemurahan hati Allah lebih besar dari pada dosa yang diperbuat manusia. Dan, karena hal itu pulalah, manusia secara sadar mengakui segala kesalahannya dan kemudian kembali kepada Allah.

Tujuan dari karya keselamatan ini adalah terciptanya 'damai sejahtera'. Kedua kata ini mempunyai makna yang cukup luas. Dalam Perjanjian Lama, damai sejahtera dipakai untuk menggambarkan situasi di mana manusia mendapatkan keselamatan yang datang dari Allah. ${ }^{2}$ Tetapi damai sejahtera dapat pula diartikan sebagai keadaan di mana manusia dapat hidup berdampingan dengan saling menghormati, mencintai dan menghargai atau dapat pula dikatakan secara negatif: tidak adanya tindakan-tindakan intoleransi, radikalisme, pembunuhan, anarkisme dan tindakan-tindakan buruk lainnya yang dapat merusak tatanan damai masyarakat dunia.

Tetapi, apa yang ingin diberikan oleh Allah ini sifatnya adalah sebuah tawaran. Tawaran belum tentu akan diambil oleh orang yang ditawari. Allah dengan kemurahan hatinya ingin menyelamatkan manusia, tetapi apakah manusia mempunyai keinginan untuk menyambut tawaran keselamat Allah ini. Tawaran ini pulalah yang akan menjadi titik tolak penulis dalam melakukan penelitian terhadap ritual pembakaran tongkang di Bagansiapiapi. Ritual ini merupakan ritual wajib bagi warga keturunan Tionghoa di Bagansiapiapi; bahkan - mungkin - bukan hanya mereka yang tinggal di kota tersebut, tetapi mereka yang pernah tinggal di kota itu akan kembali ke Bagansiapiapi hanya untuk berdoa dan mengikuti ritual tersebut. Peristiwa ini menggelitik dan menarik minat penulis.

Ada begitu banyak pertanyaan yang kemudian muncul dalam benak penulis ketika penulis mendapatkan cerita tentang budaya ritual ini. Susanne K Langer di dalam bukunya Philosophy in A New Key mengatakan bahwa ritual adalah suatu bentuk simbol. Ritual merupakan sebuah simbol bagi orang-orang yang melakukannya. Maka, pertanyaan dasar dari tulisan ini adalah "Makna simbol apa yang ingin disampaikan lewat ritual ini?". Pertanyaan ini muncul karena meskipun mereka tinggal jauh dari Bagansiapiapi, mereka rela untuk kembali dan merayakannya. Pertanyaan yang kemudian juga akan dicoba dijawab dalam tulisan ini adalah "Keselamatan apa yang ingin ditawarkan melalui ritual ini dan yang juga menjadi kerinduan mereka?". Pertanyaan-pertanyaan ini akan coba penulis jawab sembari mencari makna simbol dalam ritual bakar tongkang ini dari prespektif teologi, khususnya soteriologi.

\section{GELIAT HIDUP ETNIS TIONGHOA DI BAGANSIAPIAPI}

Bila ditilik dari sejarah, Indonesia dan Tiongkok sebenarnya mempunyai hubungan sejarah yang cukup panjang. Salah satu buktinya adalah banyaknya etnis Tionghoa yang ada di Indonesia dan tersebar di berbagai daerah di Indonesia. Berdasarkan data BPS tahun 2010, seperti dikutip oleh Portal Informasi Indonesia INDONESIA.GO.ID, ${ }^{3}$ etnis Tionghoa di Indonesia berjumlah 2.832.510 atau sekitar 1,2\% dari total penduduk Indonesia yang berjumlah 237.641.326 jiwa (laju pertumbuhan per tahun 1,49\%). ${ }^{4}$ Bahkan 
ada pula pendapat bahwa nenek moyang bangsa Indonesia berasal dari daerah Yunnan, Tiongkok Barat Daya. ${ }^{5}$ Sebagai bukti lainnya adalah adanya klenteng Sam Poo Kong di Semarang. Di dalam klenteng tersebut ada patung besar Laksamana Zheng He (郑和). Zheng He pernah berlayar sampai ke Indonesia dan menjadi salah satu penyebar agama Islam di beberapa daerah di Indonesia. ${ }^{6}$ Dari beberapa bukti tersebut cukup jelaslah bahwa hubungan antara Indonesia dan Tiongkok sudah terjalin dengan baik sejak beratus-ratus tahun yang lalu.

Hubungan yang baik ini hingga kini masih terus-menerus dilanjutkan. Meskipun beberapa kali warga etnis Tionghoa di Indonesia mengalami perlakuan yang kurang baik; terutama ketika situasi ekonomi dan politik Indonesia kurang begitu baik, maka etnis Tionghoa yang akan menjadi sasaran "kambing hitam"-nya. Peristiwa kerusuhan yang terjadi pada masyarakat etnis Tionghoa - dan masih sangat hangat dipikiran meski sudah berlangsung 12 tahun yang lalu - adalah kerusuhan Mei 1998. Kerusuhan ini terjadi di beberapa kota di Indonesia dan etnis Tionghoa adalah kelompok masyarakat yang paling dirugikan karena mengalami perlakuan kasar; baik secara verbal, psikologis, maupun seksual. Etnis Tionghoa menjadi korban kegalauan massa pada saat itu. Luka itu juga membawa trauma yang berkepanjangan sehingga banyak dari mereka yang akhirnya bersekolah dan kemudian tinggal di luar negeri.

Tetapi peristiwa ini tidak hanya berbuah pahit, tetapi juga berbuah manis karena sejak peristiwa itu rasa kepercayaan diri etnis Tionghoa di Indonesia sedikit demi sedikit mulai ditumbuhkan. Peraturan-peraturan yang membatasi ruang gerak dan mendiskriminatif mereka mulai dihapus- kan. Perayaan Imlek yang sejak orde baru dilarang mulai diberi tempat kembali, bahkan Imlek dijadikan sebagai hari libur nasional. ${ }^{7}$ Peraturan lainnya adalah pencabutan pembedaan terminologi 'pribumi' dan 'non-pribumi', pencabutan pelarangan tentang agama dan budaya Tiongkok, dan status kewarganegaraan etnis Tionghoa. ${ }^{8}$ Dengan pencabutan beberapa peraturan yang membatasi ruang gerak dan mendikriminatif ini, etnis Tionghoa di Indonesia mendapatkan angin segar untuk mengekspresikan budaya, agama, dan kepercayaan mereka sehingga kesadaran sebagai bagian dari bangsa dan negara ini semakin dipulihkan dan aktualisasi dari kekayaan budaya mereka dapat menambah kekayaan budaya Indonesia.

Apa yang dirasakan oleh etnis Tionghoa di bagian lain di Indonesia, juga dirasakan oleh etnis Tionghoa di kota Bagansiapiapi. Sebagai keterangan, Bagansiapiapi terletak di Kecamatan Bangko, Kabupaten Rokan Hilir, Provinsi Riau. Kabupaten ini mempunyai luas $8.881,59 \mathrm{~km}^{2}$ dan merupakan pemekaran dari Kabupaten Bengkalis berdasarkan Undang-undang no. 53 Tahun 1999. ${ }^{9}$ Kabupaten ini mempunyai 18 kecamatan dan salah satunya adalah kecamatan Bangko. Di kecamatan Bangko inilah Bagansiapiapi terletak. Di Bagansiapiapi, etnis Tionghoa sudah sejak lama tinggal di sana. Biasanya mereka tinggal di pusat kota. Mereka meyakini bahwa nenek moyang mereka berasal dari daerah Siam, Thailand. ${ }^{10}$ Mereka melarikan diri ke pulau itu karena pada saat itu mereka akan dibunuh oleh orang-orang Thailand. Yang menjadi penyebabnya adalah rasa cemburu karena warga etnis Tionghoa ini cukup beruntung dalam bidang bisnis dan ekonomi sehingga mereka menjadi orang kaya di negara orang tersebut. Tetapi untunglah ada dari mereka yang mempunyai kekasih orang pribumi sehing- 
ga rencana pembunuhan itu didengar oleh mereka. Maka, kemudian mereka bergegas untuk lari dari Thailand. Menurut cerita, sebenarnya ada tiga kapal yang membawa etnis Tionghoa dari Thailand. Tetapi hanya dua kapal saja yang mendarat dengan selamat, sedang yang satunya tidak pernah didengar kabarnya hingga hari ini. Yang menarik dari kisah pelarian ini adalah adanya karya keselamatan. Konon, ketika mereka mengalami kebingungan dalam menentukan arah, mereka bertanya kepada patung dewa laut terlebih dahulu. Karena keteguhan mereka selalu meminta pertolongan inilah, akhirnya mereka menemukan dataran baru yang akan menjadi kisah baru dalam kehidupan mereka.

Bila dilihat dari segi ekonomi, saat ini kehidupan etnis Tionghoa di Bagansiapiapi sudah jauh lebih baik. Tempat tinggal yang tidak jauh dari pantai, membuat sebagian dari mereka hidup sebagai nelayan. Pada beberapa tahun yang lalu, karena hasil ikannya yang melimpah, kota ini terkenal sebagai penghasil ikan di dunia. Sekarang, matapencaharian di sana sudah lebih banyak beragam. Etnis Tionghoa dikenal sebagai kelompok masyarakat yang tekun, ulet dan menjadi motor perekonomian di kota ini. Hidup mereka gantungkan dari hasil membuka toko, menjual hewan dan makanan hewan, membuka rumah makan dan beberapa usaha lainnya. Salah satu usaha yang cukup mencolok di kota ini adalah usaha sarang burung walet. Di kota ini ada banyak sekali bangunan tinggi yang digunakan sebagai rumah burung walet. Maka, tak heran bila rekaman suara burung walet menjadi salah satu kekhasan di kota ini. Rekaman suara burung ini diputar terus-menerus sepanjang hari agar burung-burung itu masuk ke dalam rumah-rumah itu kemudian membuat sarang di sana. Memang, sarang burung walet dari Indonesia cukup terkenal di negara Tiongkok.

Dari segi rumah sendiri, beberapa rumah dari mereka masih mempertahankan rumah yang dibuat dari kayu. Beranda rumah pasti ada karena di tempat inilah terjadi proses sosialisasi antar warga masyarakat dan juga dapat menjadi sarana bagi mereka ketika ingin membuka usaha kecil-kecilan. Tetapi ada pula rumah yang sudah terbuat dari batu bata dan semen. Rumah-rumah ini dibangun ulang karena pada Mei 1998 mereka juga menjadi korban kerusuhan di kota tersebut. Sehingga mau tidak mau mereka harus membangunnya ulang. Yang menarik dari tipe rumah mereka adalah adanya tempat sembahyang. Tempat sembahyang ini biasanya terletak di ruang depan sehingga ketika kita memasuki rumah mereka, tempat sembahyang inilah yang akan kita lihat pertama kali. Tempat sembahyang ini menjadi sarana perjumpaan mereka dengan Tuhan yang mereka sembah dan leluhur mereka.

Dalam segi keagamaan, orang-orang Tionghoa di sana kebanyakan beragama Budha dan/atau Khonghucu. Mereka biasanya berdoa di rumah maupun di klenteng. Maka, tidak mengherankan bila di daerah ini - menurut data dari Badan Pusat Statistik Kabupaten Rokan Hilir - terdapat sekitar 25 klenteng dan yang terbesar adalah klenteng In Hok Kiong. Klenteng In Hok Kiong adalah klenteng tertua di daerah ini dan di klenteng ini pulalah perayaan ritual bakar tongkang akan dimulai. Selain adanya tempat sembahyang, di rumah-rumah mereka juga dipasang beberapa simbol keagamaan, seperti patung dewa/dewi, patung macan, tempelan di atas pintu dan lain sebagainya. Pengalaman diselamatkan oleh dewa laut sepertinya cukup membekas di dalam kehidupan etnis Tionghoa di sana secara 
turun-temurun. Dan, ritual bakar tongkang juga menjadi salah satu bukti ketaatan mereka pada pemberi keselamatan. Di dalam hidup kepercayaan, mereka juga masih percaya dengan apa yang disebut tangki. Tang$k i$ adalah manusia yang menjadi sarana dewa untuk bertindak ataupun memberikan pesan. Untuk menjadi tangki bukan suatu hal yang mudah. Tangki adalah orang yang ditunjuk oleh dewa sendiri. Kalau orang itu setuju dengan penunjukkan itu, maka dia harus menjalani beberapa ritual. Ritual itu antara lain: selama tiga hari dia harus bertapa di dalam ruangan yang gelap dan hanya diperbolehkan makan tujuh butir beras dan satu gelas teh. Setelah itu, ritual berikutnya adalah memasukkan tangan ke dalam minyak panas yang dicampur dengan pasir. Ritual ini bertujuan untuk membersihkan, mempersiapkan dan melindungi dirinya sendiri. Setelah semua ritual itu dijalankan, maka dia sudah siap untuk menjadi seorang tangki. Karena dia menjadi sarana komunikasi antara dewa dengan masyarakat lainnya, maka dia juga mempunyai kewajiban untuk selalu membersihkan dirinya dengan berbagai cara, seperti: tidak minum alkohol, berpuasa, mati raga, mengatakan hal-hal positif dan berbagai cara lainnya sehingga dia dianggap pantas untuk menerima rahmat itu.

Dalam bidang sosial kemasyarakatan, etnis Tionghoa di Bagansiapiapi hidup berdampingan dengan etnis-etnis lainnya. Peristiwa Mei 1998 memang meninggalkan trauma yang cukup dalam di kalangan anak mudanya. Sehingga terkadang masih ada perasaan curiga bila bertemu dengan etnis lain. Mereka lebih nyaman ketika berjumpa dengan sesama etnis Tionghoa. Hal ini berakibat pada terkotak-kotaknya pola relasi antara warga Tionghoa dan etnis lainnya. Mereka lebih senang berkumpul di antara sesama warga Tionghoa lainnya. Hal ini ditambah lagi dengan penggunaan Bahasa Mandarin - khususnya Hokkian - di dalam interaksi antar sesama warga Tionghoa. Meski begitu, sudah dimulai pula oleh beberapa warga Tionghoa di sana untuk berani menjalin relasi dengan warga dari etnis lainnya. Peristiwa Mei 1998 memang membekas, tetapi rekonsiliasi diantara mereka juga terus-menerus dilakukan.

Dalam bidang kebudayaan, ritual bakar tongkang di Bagansiapiapi merupakan kegiatan budaya yang cukup membawa nama kota ini terkenal; baik di dalam negeri maupun di luar negeri. Ketika ritual ini tiba banyak wisatawan akan datang ke Bagansiapiapi. Tujuan mereka datang ke kota ini adalah untuk melihat langsung bagaimana upacara itu diadakan. Tetapi ada pula yang mereka memang datang untuk berdoa dan memohon berkat. Pada era reformasi, ritual ini digarap semakin serius oleh seluruh masyarakat Bagansiapiapi bekerjasama dengan Pemerintah setempat. Beberapa hotel sudah mulai dibangun di pusat kota. Pemerintah juga memberikan dukungan dengan mempromosikan ritual ini ke berbagai daerah dan negara dengan pembuatan buku dan leaflet. Kiranya, ritual pembakaran tongkang sekarang ini bukan hanya sebatas kegiatan ritual etnis Tionghoa di Bagansiapiapi saja, tetapi juga merupakan kegiatan bersama karena melalui peristiwa ini ketegangan yang terjadi karena peristiwa Mei 1998 dapat dikikis sedikit demi sedikit dan pariwisata budaya di kota Bagansiapiapi akan berkembang.

\section{RITUAL BAKAR TONGKANG: ANTARA PERISTIWA, SIMBOL DAN MAKNA}

Upacara ritual bakar tongkang adalah acara tahunan yang dilakukan oleh etnis Tionghoa di kota Bagansiapiapi. Ritual ini 
merupakan warisan nenek moyang mereka yang terus-menerus dilakukan. Ritual ini sendiri sudah berlangsung sejak 128 tahun yang lalu. Tujuan dari ritual ini sendiri adalah untuk menghormati hari kelahiran Dewa Laut atau yang juga dikenal dengan nama Kie Ong Yang. Biasanya, ritual ini dilakukan pada tanggal 16 bulan 5 dalam kalender Lunar atau orang di Bagansiapiapi menyebutnya Cap Ge Cap Lak. Pada bagian ini, penulis ingin mencoba membahas mengenai urutan ritual bakar tongkang, materi yang digunakan, para pelaku dan simbol-simbol yang terdapat di dalamnya.

Upacara ritual bakar tongkang sudah dimulai sejak beberapa bulan sebelum hari perayaan. Upacara ini dimulai dengan ritual bertanya kepada dewa. Dalam ritual ini biasanya ada dua cara yang dipakai, yaitu bertanya dengan perantaraan tangki atau bertanya lewat perantaraan tandu. ${ }^{11} \mathrm{Un}$ tuk cara yang kedua ini, tandu hanya boleh dibawa oleh mereka yang sudah dipilih oleh dewa sendiri. Kedua cara ini sebenarnya merupakan bentuk komunikasi antara dewa dan manusia, antara yang disembah dengan yang menyembah. Ritual awal ini menjadi begitu penting karena - dapat dikatakan - ritual ini menjadi dasar dari semua urutan atau tata cara upacara bakar tongkang. Menjadi penting juga karena dalam ritual ini akan diketahui ukuran dan bahan yang nantinya akan dipakai untuk membuat kapal tongkang. Dengan kata lain, melalui ritual ini etnis Tionghoa di Bagansiapiapi ingin mencoba menangkap apa yang dikehendaki dari dewa tersebut. Ritual ini diikuti oleh seluruh pengurus klenteng dan lo $\mathrm{cu} .{ }^{12}$

Setelah ritual itu, proses selanjutnya adalah pembuatan kapal tongkang. Proses ini biasanya dilakukan satu bulan sebelum upacara berlangsung. Di dalam proses ini siapa pun boleh terlibat di dalam pembuatannya. Ada satu pantangan dalam proses pembuatan ini, yaitu bahwa tidak boleh hanya satu orang saja yang menjadi sponsor pembuatan kapal tongkang ini. Pantangan ini diberlakukan dengan tujuan agar berkat yang nantinya akan dianugerahkan dewa kepada manusia tidak hanya turun pada satu orang saja, tetapi berkat ini dapat dirasakan oleh semakin banyak orang. Dalam proses ini sangat kentara sekali bahwa berkat atau rahmat keselamatan yang akan dianugerahkan itu diharapkan dapat berdampak bagi banyak orang. Berkat inilah yang kemudian dicari atau diharapkan manusia. Harapan akan rahmat yang dicurahkan ini tidak saja tercermin dalam proses pembuatannya, tetapi di dalam simbol-simbol yang dipakai pun juga nampak. Kapal tongkang yang sedang dibuat ini kemudian akan dihias dengan berbagai macam ornamen yang kesemuanya merupakan simbol-simbol harapan. Ornamen-ornamen itu antara lain:

1. Bunga jin hua [Jin (金) berarti emas dan hua (花) berarti bunga]. Bunga ini diletakkan di depan dan belakang kapal sebagai simbol keagungan dan martabat.

2. Tujuh kertas doa. Tujuh kertas doa ini merupakan simbol tujuh bintang dewa yang mempunyai arti agar berkat terus-menerus dicurahkan. Yang membuat kertas doa ini adalah tangki dan tiong hia. ${ }^{13}$

3. Kepala singa dengan mata bersinar yang merupakan simbol bahwa dengan mata tersebut kapal dapat melihat segala sesuatu dengan jelas dan dapat bergerak dengan baik. Mata dari singa ini biasanya akan ditutup sampai tanggal 16 bulan 5 . 
4. Kepala naga yang diletakkan di belakang dengan harapan agar semburan naga itu dapat mempercepat kapal berlayar.

5. Kuda terbang merupakan simbol bahwa meskipun berada di daratan kapal tersebut masih tetap berjalan dengan bantuan para kuda tersebut.

6. Qi pai jiang (旗牌将) yang berarti 29 bendera jenderal.

7. Kru kapal yang digambarkan dengan tugas masing-masing.

Ritual kemudian dilanjutkan pada seminggu sebelum upacara ritual bakar tongkang diadakan. Ritual ini dinamakan pemanggilan lima dewa penjaga. Para dewa ini adalah penjaga segala penjuru arah mata angin (Tengah, Timur, Selatan, Barat dan Utara). Para dewa itu adalah dewa Naca yang menjaga bagian tengah dari pertemuan keempat penjuru arah mata angin, dewa guntur yang menjaga arah Timur, dewa angin yang menjaga arah Selatan, dewa perang yang menjaga arah Barat dan dewa Utara yang menjaga arah Utara. Para dewa ini dipercaya mempunyai sejumlah pasukan yang dengan setia selalu membantu mereka.

Ritual pemanggilan para dewa penjaga ini dilakukan oleh para tiong hia. Seorang tiong hia akan menari di depan meja altar dengan menggunakan pakaian khusus, membawa bendera dan huat so. ${ }^{14}$ Setelah tiong hia tersebut selesai menari di dalam, mereka kemudian akan berjalan keluar untuk menuju ke tempat pembakaran kertas doa. Tempat pembakaran kertas ini berbentuk sebuah lingkaran besar. Di tempat itulah para tiong hia akan menari - seorang tiong hia menari dengan memegang lima bendera kecil, sedangkan yang seorang lainnya akan menari sambil membawa bendera besar berbentuk segitiga dan di bendera itu terdapat gambar lima dewa penjaga. Setelah selesai menari, bendera besar itu kemudian ditancapkan di samping tempat pembakaran. Kemudian tempat pembakaran itu diisi penuh dengan kertas doa dan dibakar. Sejak saat itu setiap malam para tiong hia ini akan menari. Tujuan mereka menari adalah untuk mengundang dan menghormati para dewa penjaga. Para dewa penjaga ini diundang agar mereka ikut serta dalam menjaga segala proses perayaan ini sehingga perayaan ini dapat berlangsung dengan aman dan lancar.

Dalam ritual ini sangat nampak sekali harapan yang besar akan berhasilnya perayaan itu. Harapan yang besar itu mengandung arti bahwa perayaan itu begitu penting bagi mereka dan dimungkinkan juga bahwa perayaan itu berkaitan - sambung - dengan kehidupan mereka. Dengan kata lain, bahwa perayaan itu mempunyai pengaruh yang cukup besar di dalam kisah hidup mereka sehingga harapan yang besar akan berhasilnya acara itupun dibangun dan segala ritual dilakukan dengan penuh kehati-hatian dan teliti.

Ritual kembali dilanjutkan pada tanggal 15 bulan 5 dalam kalender Lunar. Pada ritual kali ini, tandu yang menyimbolkan kehadiran dewa laut dibawa keluar oleh tangki. Di depan tandu tampak para tiong hia menari sesuai dengan posisi mereka masing-masing. Posisi ini ditentukan dari pakaian yang mereka pakai. ${ }^{15}$ Setelah para tiong hia selesai menari, tandu dewa laut dibawa ke depan altar dan lewat perantaraan tandu itu dewa laut akan menulis sesuatu di meja altar. Kemudian tiong hia akan kembali menari di depan altar. Ketika sudah selesai menari, lo cu akan masuk ke dalam klenteng kemudian berlutut di depan altar dan berdoa. Kemudi- 
an tiong hia akan menari lagi. Setelah itu, tandu dewa laut, tangki, tiong hia, dan lo cu akan keluar dari klenteng untuk melakukan ritual di luar klenteng. Ritual yang sama akan dilakukan di luar klenteng. Yang membedakannya adalah ritual itu dilakukan sebanyak tiga kali dengan tiga tempat yang berbeda dan lo cu akan diperciki oleh tiong hia dengan menggunakan campuran beras dan garam. Setelah upacara di luar selesai, mereka akan masuk kembali ke dalam klenteng. Di dalam klenteng, lo cu kembali berlutut di depan meja altar. Tangki maju ke depan altar dan membaca apa yang dikehendaki oleh dewa laut. Setelah itu, sekali lagi, tiong hia menari di depan meja altar.

Ritual kemudian dilanjutkan dengan peresmian Ling Sao Bao Tian. Peresmian ini dilakukan dengan memercikinya dan membubuhkan tinta merah di keseluruhan bagian Ling Sao Bao Tian. Ling Sao Bao Tian merupakan simbol dari tempat tinggal Dewa Tertinggi. Yang menarik dari ritual ini adalah ketika tinta merah dibubuhkan pada Ling Sao Bao Tian, semua warga yang datang akan meneriakkan 'huat' yang berarti keberuntungan. Hal ini ingin mengatakan bahwa dengan adanya ritual ini diharapkan rahmat melimpah dari Tuhan ikut hadir menyertai dan semoga keberuntungan selalu dianugerahkan kepada mereka yang hadir.

Di dalam ritual pada hari ini, masyarakat yang hadir juga memberikan persembahan berupa makanan yang berbentuk kambing atau babi sebagai simbol kebesaran dan buah-buahan. Salah satu buah yang sering menjadi bahan persembahan adalah pisang karena bagi mereka pisang adalah simbol pemersatu.

Pada tanggal 16 bulan 5 penanggalan Lunar, upacara ritual bakar tongkang dilanjutkan kembali. Pada hari ini ada beberapa ritual yang dilakukan, yaitu: dikeluarkannya kembali tandu dewa laut untuk melihat kembali apa yang dikehendaki sang dewa, dibakarnya Ling Sao Bao Tian, dan perarakan kapal ke klenteng In Hok Kiong. Dikeluarkannya kembali tandu dewa laut oleh tang$k i$ yang ditunjuk bertujuan untuk menegaskan kembali apa yang menjadi kehendak dan keinginan dewa laut sehingga apa yang akan dilakukan oleh manusia mendapatkan persetujuan dan restu dari sang dewa dan dengan itu semua, keselamatan yang diharapkan oleh mereka yang terlibat dapat terwujud. Tujuan lain dikeluarkannya tandu dewa laut adalah juga untuk mengantar Ling Sao Bao Tian ke tempat pembakaran. Arak-arakan itu biasanya akan diikuti tandu-tandu dewa lainnya dan para tangki. Di setiap persimpangan jalan mereka akan berputar-putar untuk membersihkan jalan yang akan dilalui itu dari segala roh jahat dan segala gangguan sehingga arak-arakan bisa sampai ke tempat pembakaran dengan selamat, damai dan lancar. Dalam ritual ini, kata huat terus-menerus diucapkan sebagai sebuah permohonan dan harapan agar keberuntungan selalu datang; agar rahmat keselamatan selalu dilimpahkan.

Ritual ketiga hari ini adalah perarakan kapal tongkang menuju klengteng In Hok Kiong. Pada ritual ini ada dua peristiwa. Pertama, dibukanya kain yang menutupi kepala singa atau yang disebut kai yan (开眼 = membuka mata). ${ }^{16}$ Kedua, diresmikannya kapal tongkang itu. Setelah kain penutup dibuka maka para petugas akan memercikkan air suci, menyebarkan campuran garam dan beras, dan menandai dengan tinta merah pada keseluruhan bagian kapal. Pada ritual ini tandu dewa laut berada dihadapan kapal tongkang itu, begitu pula dengan lo cu. 
Ritual bakar tongkang ini berpuncak pada tanggal 17 bulan 5 kalender Lunar. Pada hari itu, kapal tongkang akan diarak menuju ke tempat pembakaran. Perarakan itu akan diikuti oleh para tangki, tandu para dewa, persembahan berupa nanas berwarna emas yang terbuat dari kertas doa, lo cu dan para peziarah. ${ }^{17}$ Di setiap persimpangan, tandu yang dibawa akan berputar-putar, campuran garam dan beras akan disebarkan dan tangki akan beratraksi. Tujuan dari kesemuanya itu adalah pembersihan jalan yang akan dilalui sehingga terhindar dari gangguan roh-roh jahat dan perjalanan kapal tongkang dari klenteng ke tempat pembakaran dapat berjalan dengan lancar. Setelah sampai di tempat pembakaran, kapal tongkang akan diletakkan berhadapan dengan dewa laut dan di sekitarnya diletakkan kertas doa. Setelah semuanya siap, kapal kemudian dibakar. Mereka yang hadir akan menunggu sampai tiang tongkang itu jatuh karena arah jatuhnya tiang tongkang itu dipercaya menjadi pertanda arah datangnya rejeki pada hari-hari berikutnya. Yang menarik pula dari kapal tongkang tersebut adalah tulisan yang dituliskan di bagian layar kapal itu. Tulisan itu berbunyi 合境平安 (hé jìng píng ān) dan 一帆风顺 (yī fān fēng shùn) yang berarti semoga segala sesuatu dapat berjalan dalam keharmonisan, damai dan lancar. Dengan harapan ini, sebenarnya mengandung arti pula bahwa agar kehidupan yang akan mereka jalani dapat berjalan dengan baik, mendapatkan banyak rejeki dan harmonis.

Upacara ritual bakar tongkang yang berlangsung lebih dari satu bulan ini cukup menarik untuk dibahas. Di dalamnya ada banyak simbol yang ingin memberikan informasi kepada siapapun yang mengikuti atau hanya sekedar menjadi penonton. Simbol-simbol itu mengandung makna yang cukup dalam karena harapan yang besar dari perayaan itu tergantung di sana. Pada bagian berikut penulis ingin mencoba membedah ritual tersebut dari sudut pandang teologi keselamatan dalam tradisi Katolik.

\section{TAWARAN KESELEMATAN: SEBUAH REFLEKSI TEOLOGIS}

Bagi Susanne K Langer, ritual dan mitos adalah bagian dari simbolisasi yang dibuat oleh manusia. ${ }^{18}$ Ritual dan mitos tercipta karena keinginan manusia dalam mengekspresikan perasaan dan situasi yang sedang dialaminya. Maka, ritual dan mitos adalah sebuah simbol. Dalam konteks ini, ritual dan mitos di dalam upacara pembakaran tongkang di Bagansiapiapi juga merupakan sebuah ekspresi dari masyarakat Tionghoa yang tinggal di Bagansiapiapi maupun yang berasal dari luar. Apa yang sedang mereka alami dan situasi seperti apa yang sedang melingkupinya menjadi bagian yang tidak terpisahkan dari upacara tersebut. Semuanya berada dalam satu muara: harapan akan keselamatan. Atau, dalam konteks ini - seperti yang selalu mereka ucapkan 'huat' - adalah keberuntungan.

Keselamatan merupakan harapan bagi setiap manusia. Siapapun itu pasti selalu mengharapkan keselamatan di dalam kehidupannya. Keselamatan dapat diartikan sebagai kesejahteraan, damai, sukacita, keberuntungan, kebahagiaan dan lain sebagainya. Lawan dari keselamatan adalah kemalangan yang diartikan sebagai keadaan yang kurang menguntungkan, bencana, gempa bumi, kecelakaan dan sebagainya. ${ }^{19}$ Maka, keselamatan adalah keadaan yang selalu diidamkan, sedangkan kemalangan adalah keadaan yang selalu dihindari. Dalam kaitannya dengan hal ini, upacara ritual bakar tongkang juga merupakan salah satu sarana manusia untuk mendapatkan kese- 
lamatan itu dan menghindari kemalangan. Tapi, bagaimana bentuk dan maknanya? Berikut penulis mencoba untuk merumuskannya.

\section{Adanya Konsep yang Transenden}

Dikatakan bahwa manusia adalah makhluk yang paling sempurna, makhluk yang paling tinggi martabatnya karena hanya manusia yang dikarunia akal budi dan dalam teologi Katolik, manusia juga diyakini sebagai makhluk yang diciptakan secitra dengan Allah (Kej 1:26). Akal budi dan keyakinan diri sebagai makhluk ciptaan yang bermartabat menjadi modal manusia untuk mengelola bumi dan alam ciptaan lainnya. Sehingga di zaman yang serba modern ini, manusia bisa menemukan berbagai informasi yang ingin didapatkannya. Internet memberikan keuntungan dan kemudahan luar biasa. Saat ini segala pertanyaan dapat dengan mudah mendapatkan jawabannya di dunia maya. Bahkan tidak hanya itu, kemajuan teknologi juga membuat jejaring komunikasi lebih hemat dan cepat. Kalau pada zaman dahulu orang harus menunggu beberapa hari untuk saling berkabar, sekarang hanya dalam hitungan detik orang bisa saling berkabar. Jarak tempat bukan lagi menjadi penghalang manusia dari berbagai penjuru untuk bertemu. Dengan kemajuan teknologi, manusia dari berbagai penjuru dapat bertemu, saling memandang dan saling bercerita lewat perantaraan dunia maya. Ini semua adalah berkat daya pikir manusia yang begitu besar. Memahami bahwa manusia mempunyai keterbatasan, maka mereka berpikir bagaimana cara mengatasi keterbatasan itu.

Melalui karunia pikiran manusia tidak hanya mengembangkan apa yang berada di luar dirinya, tetapi juga mengembangkan apa yang dimilikinya. Persaudaraan, kebaikan, kejujuran, kedisiplinan diri dan lain sebagainya merupakan hal-hal yang dimiliki manusia secara alami. Persaudaraan dikembangkan manusia dengan tetap menjalin relasi yang baik bagi siapa saja dan dari persaudaraan itu kemudian berbuah solidaritas. Kebaikan senantiasa dilakukan manusia dalam menjalin relasinya dengan sesama manusia maupun ciptaan lainnya. Kejujuran dan kedisiplinan diri dilakukan manusia di dalam berbagai bidang kehidupan; salah satunya adalah dalam dunia kerja. Lewat akal budi yang dikarunikan Allah, manusia terus-menerus berkembang.

Tetapi tidak semua dapat diatasi oleh manusia; tidak semua dapat dipahami oleh manusia. Ada bagian-bagian tertentu di dalam kehidupannya manusia benar-benar mengalami keterbatasannya. Sebagai contohnya adalah ketika manusia berada dalam situasi yang "baru", seperti: kelahiran, pernikahan, kematian dan contoh lainnya. Peristiwa-peristiwa itu kemudian membuat manusia bertanya 'Apa yang akan saya lakukan sekarang?'. Artinya, dengan pertanyaan itu, manusia berhadapan dengan ketidakpastian dan mencoba untuk mencari kepastian di dalam hidupnya; baik itu dengan membuat rencana maupun sekedar menerima saja secara pasif. Hal-hal yang sering menjadi pertanyaan manusia juga adalah berkaitan dengan kematian, seperti: bagaimana hidup setelah kematian, apa yang terjadi ketika manusia meninggal dan sebagainya. Ditambah lagi bila manusia kemudian berhadapan dengan penyakit atau kemalangan yang menyebabkan kematian secara massif. Materi-materi tadi merupakan pertanyaan yang sulit dijawab oleh manusia. Memang, masing-masing manusia mempunyai impian dan cita-cita akan arah hidupnya di masa datang. Tetapi, arah kehidupan itu belum dapat menjadi kenyataan ketika manusia belum mengalami; bisa jadi apa yang menja- 
di perjalanan hidupnya saat ini berbeda dengan impian atau cita-citanya.

Berhadapan dengan aneka hal tersebut, manusia kemudian mengalami ketakutan. Tetapi ketakutan inilah yang kemudian membawa manusia masuk ke dalam sebuah kesadaran bahwa ada sesuatu yang lebih superior dari manusia; bahwa ada sesuatu yang lebih berkuasa dibandingkan dengan manusia. Berhadapan dengan makhluk ciptaan lainnya, manusia sebenarnya juga tidak lebih berkuasa. Manusia mungkin dapat mempergunakan apa yang ada di dunia ini (alam dan hewan) untuk keperluannya sendiri, tetapi ketika mereka "memberontak" manusia akhirnya akan menyerah pula. Maka, sepertinya tidak ada tempat yang aman bagi manusia. Untuk itulah manusia - berbondong-bondong - menyadari dan kemudian datang kepada Yang superior. Yang superior inilah yang dikenal dengan nama Yang Transenden, roh yang mengatasi segala-galanya, roh yang dipercaya dapat melindungi manusia dari berbagai ancaman (termasuk ancaman dari ketakutannya itu). Di dalam berbagai Bahasa, biasanya mereka menyebut-Nya dengan nama: Tuhan, Allah, God atau Yahwe.

Dalam ritual ini, konsep Yang Transenden juga dihadirkan. Konsep Yang Transenden hadir dalam wujud Dewa Tertinggi atau biasa disebut Tian atau Shàng Dì (上 帝). Tian dalam keyakinan Tionghoa diyakini hadir untuk memberikan keselamatan dalam wujud kebahagiaan, kesejahteraan, dan kedamaian. Hubungan yang baik senantiasa dijalani dengan terus-menerus membangun relasi yang harmonis antara manusia dan Tian. Relasi yang harmonis pun sedapat mungkin juga diwujudkan dalam bentuk relasi antara manusia - manusia dan manusia - makhluk ciptaan hidup lainnya.
Di dalam konteks ritual bakar tongkang ini, Yang Transenden secara nyata dihadirkan lewat Ling Sao Bao Tian yang adalah penggambaran tempat tinggal Yang Transenden tersebut dan dewa laut yang digambarkan kehadirannya lewat tandu. Kedua makhluk adikodrati ini dipercaya dapat mendatangkan keselamatan bagi mereka lewat perlindungan yang senantiasa diberikan oleh mereka.

Keyakinan akan perlindungan yang diberikan itu bersumber dari pengalaman hidup warga Tionghoa yang ada di Bagansiapiapi. Di dalam kisah hidup yang terus-menerus diturunkan dari generasi ke generasi, makhluk adikodrati itu telah membantu nenek moyang mereka di saat mereka mengalami ketakutan dan kebingungan akan kehidupan mereka. Ketidaktahuan mereka pada daratan yang akan disinggahi dan ketidaktahuan mereka pada bagaimana mereka akan hidup adalah sumber ketakutan mereka pada saat itu. Tetapi ketakutan itupun menjadi sirna ketika Tuhan dengan perantaraan dewa laut membimbing mereka menemukan daratan yang kemudian menjadi tempat singgah mereka secara turun-temurun hingga saat ini dan - tidak hanya itu - pula memberi mereka rejeki lewat hasil laut yang begitu melimpah. Pengalaman inilah yang terus-menerus dihidupi oleh mereka seraya menghidupkan ritual bakar tongkang untuk bersyukur dan memohon rahmatnya.

Penggambaran dewa laut yang hadir di dalam hidup mereka adalah penggambaran Allah yang senantiasa hadir di dalam kisah hidup manusia. Kehadiran Allah adalah untuk menyelamatkan. Pengalaman etnis Tionghoa di Bagansiapiapi semakin menegaskan bahwa Tuhan, Allah atau Yang Transenden itu ada dan akan senantiasa membantu manusia. Pertolongan dewa laut yang 
datang untuk menolong dengan memberikan arah perginya kapal pada saat itu merupakan pengalaman transendental dalam hidup mereka. Mereka dapat singgah ke sebuah pulau yang melimpah hasil buminya adalah berkat doa yang senantiasa mereka lakukan ketika mereka mengalami persimpangan jalan yang membingungkan. Di sinikah konsep Yang Transenden itu hadir untuk menenangkan dan memberikan petunjuk kepada mereka. Maka, di dalam peristiwa hidup inilah, kisah Allah yang turun ke dalam kehidupan manusia itu menjadi nyata.

Kesadaran mereka akan adanya yang transenden itu mendatangkan rahmat yang besar di dalam hidup mereka. Rahmat keselamatan dari Tuhan inilah yang kemudian ingin dicari dan didapatkan oleh etnis Tionghoa di Bagansiapiapi lewat perantaraan dewa laut yang dilangsungkan dalam upacara ritual bakar tongkang. Dalam teologi Augustinus, rahmat itu juga diartikan sebagai keadaan manusia yang selamat. ${ }^{20}$ Dalam konteks ini, rahmat keselamatan diartikan sebagai penentuan arah datangnya rejeki yang disimbolisasikan dengan arah jatuhnya tiang tongkang. Arah jatuhnya tiang tongkang itu menjadi prasyarat pekerjaan apa yang akan mereka lakukan di harihari mendatang sehingga keberuntungan itu datang dalam keluarga mereka.

\section{Dosa dan Belas Kasih Allah}

Allah senantiasa memberikan rahmat-Nya secara cuma-cuma dan karena adanya rahmat itu manusia menanggapinya dengan iman kepercayaan mereka. Di sinilah hubungan antara wahyu dari Allah dan iman dari manusia menjadi nampak. Hubungan ini terus-menerus terjadi sejak manusia itu diciptakan. Karena belas kasihan Allah, manusia memperoleh hidupnya di dunia ini dan hal itu melulu karena $k e$ - baikan Sang Pencipta (Kej 2:4-25). ${ }^{21}$ Dan tidak hanya kehidupan saja, di dalam Kitab Kejadian - terutama di dalam kisah penciptaan - Allah sudah menyediakan segala sesuatunya bagi manusia; baik itu binatang maupun tumbuh-tumbuhan yang dapat membantu manusia di dalam menjalani kisah kehidupannya. Allah menyediakan semuanya itu bagi manusia dan meminta manusia untuk mengolahnya sehingga dari itu semua hanya melulu nama Allah yang disembah dan dipuja.

Pengalaman dilahirkannya manusia ke dalam dunia ini sebenarnya pertama-tama ingin menampakkan belas kasih Allah itu pula. Allah yang berbelas kasih memberikan rahmat kehidupan kepada manusia. Manusia juga dibekali-Nya dengan berbagai sarana yang ada untuk dapat mewujudkan kehidupannya yang lebih baik. Maka, karya kehidupan manusia - baik itu dalam kerja, sosial dan sebagainya - selalu berhubungan dengan karya keselamatan Allah. Karena, hubungan kasih - yang menjadi hukum pertama dan utama yang diajarkan oleh Yesus selalu berlaku dalam hubungannya dengan Sang Pencipta dan juga sesama ciptaan. Dalam hubungan kasih ini pulalah, karya keselamatan Allah terlaksana di dalam kehidupan manusia.

Tetapi, rahmat Allah itupun akhirnya dinodai pula oleh kedosaan manusia. Dosa dipahami sebagai penyebab renggangnya hubungan antara Allah dan manusia. Dosa membuat hubungan kasih itu menjadi rusak. $^{22}$ Dosa menyebabkan tidak terjalinnya hubungan manusia secara pribadi dengan Allah. Allah sebenarnya hanya menuntut kesetiaan manusia di dalam seluruh karya dan penghayatan hidupnya. Tetapi tuntutan Allah itu tidak pernah secara sempurna terlaksana. Terkadang manusia hanya jatuh 
pada kesenangan atau kenikmatannya semata. Kedosaan ini akhirnya membuat tertutupnya rahmat Allah. ${ }^{23}$ Dosa menghalangi keselamatan itu menjadi nyata di dunia. ${ }^{24}$ Manusia tidak mampu lagi - dan mungkin tidak pantas - menerima rahmat Allah tersebut.

Di dalam Perjanjian Lama, dosa berasal dari Bahasa Ibrani, yaitu hata yang berarti meleset, tidak mengenai sasaran. ${ }^{25}$ Dalam arti ini dapat dilihat bahwa dosa merupakan tindakan yang meleset, tindakan yang tidak pas atau kurang sesuai untuk dilakukan. Bila tindakan itu dilakukan maka tindakan itu akhirnya akan merusak atau mengganggu relasi yang telah ada dan yang seharusnya ada. ${ }^{26}$ Oleh karena itulah, dosa sebenarnya berkaitan cukup erat dengan paham relasional. ${ }^{27}$ Kedosaan juga tidak hanya merusak hubungan Allah dan manusia, tetapi juga merusak hubungan antara manusia dengan manusia lainnya dan ciptaan lainnya. Kedengkian, cemburu, iri, kemarahan, perusakan alam, korupsi dan bentuk kedosaan lainnya dapat membuat hubungan kasih dengan berbagai pihak itu rusak. Perbuatan kedosaan seorang manusia dapat membuat manusia lainnya cidera atau sakit. Cemburu berlebihan yang berakhir dengan terbunuhnya manusia lain; merampok karena iri dengan kepemilikan orang lain; korupsi yang dapat mengakibatkan ruginya negara; dan masih banyak perbuatan-perbuatan lainnya yang merugikan pribadi lain. Tidak hanya dengan manusia, dosa juga merusak hubungan manusia dengan makhluk ciptaan lainnya. Perusakan hutan dan semakin banyaknya binatang dan tumbuhan yang punah menjadi bukti kedosaan manusia yang dikarenakan keserakahan manusia dan menganggap dirinya sebagai penguasa dunia ini. Keserakahan manusia menjadi salah satu penyebab kedosaan yang timbul dalam tindakan manusia.

Di dalam Kitab Suci, dosa juga diartikan sebagai pelanggaran terhadap sesuatu yang suci atau sakral. ${ }^{28}$ Keselamatan dan keseimbangan di dalam sebuah masyarakat dilakukan dengan cara melakukan pelbagai aturan yang ada. Ketika seseorang melanggar salah satu aturan itu maka keseimbangan di dalam masyarakat akan terganggu (Yos 7; 2Sam 6:6-7; 1Kor 11:17-34) dan pelanggar tersebut harus mempertanggungjawabkan tindakan yang sudah dilakukannya. Di sinilah dosa juga mempunyai sisi moralnya. ${ }^{29}$ Si pelanggar harus mempertanggungjawabkan dan menjalankan hukuman yang akan diberikan kepadanya. Dalam kaitannya dengan ini pula bahwa aturan-aturan itu juga merupakan perjanjian yang dibuat antara Allah dengan manusia. Pelanggaran akan sebuah aturan atau hukum dianggap sebagai pelanggaran terhadap perjanjian tersebut; tidak setia terhadap perjanjian dan memberontak terhadap kasih Allah (Ul 10:12-16; 1Yoh 3:4). ${ }^{30}$ Maka, sekali lagi, dosa menyebabkan hubungan atau relasi kasih antara manusia dan Allah menjadi renggang. Manusia tidak mau membalas kasih yang sudah ditawarkan oleh Allah. Dosa bukan hanya sekedar melanggar hukum, tetapi lebih dari itu: berkaitan dengan hal kesetiaan kepada Allah.

Karena dosa melanggar kesetiaan Allah, dalam arti ini pula dosa merupakan lawan dari kebenaran atau dalam Bahasa Ibraninya tsedeqah dan kebenaran ini berkaitan erat dengan karya keselamatan. ${ }^{31}$ Dosa melawan kebenaran dan keselamatan yang coba ditawarkan oleh Allah (Yes 45:24; 46:13; 56:1; Mzm 22:32; 24:5). ${ }^{32}$ Relasi yang coba 
ditetapkan dan ditawarkan oleh Allah dirusak oleh sisi kedosaan manusia. Manusia tidak setia terhadap relasi itu. Dalam suratnya kepada Jemaat di Roma, Santo Paulus dengan tegas mengatakan bahwa hidup dalam iman merupakan ciri orang benar ( $\mathrm{Rm}$ 1:17). Dalam artian itu pula dapat dikatakan bahwa dengan mengikuti iman berarti manusia akan setia pada relasi perjanjian Allah dan dengan kesetiaan itu keselamatan akan dianugerahkan. Maka, hubungan antara manusia dan Allah sebenarnya adalah hubungan yang mendalam dan menyeluruh. Artinya: dengan segala kesetiaanNya, Allah setia kepada manusia sesuai dengan relasi perjanjian yang telah dibuatNya; tetapi dari sisi manusia terkadang ada sikap keengganan untuk melakukan yang sama seperti yang dilakukan Allah. Di sinilah dosa itu mulai tumbuh dan merusak semua relasi yang sudah sejak awal dimulai oleh Allah sendiri.

Dalam ritual bakar tongkang ini juga ditampilkan sisi kerapuhan manusia, yaitu dosa. Dosa dianggap sebagai penghambat turunnya keselamatan kepada seseorang atau keluarga. Sumber dosa ini bisa berasal dari banyak hal, antara lain: hubungan yang kurang harmonis dengan keluarga, saudara ataupun masyarakat sekitar; bersikap kurang hormat kepada Tuhan atau dewa; berlaku kurang baik kepada sesama manusia; dan berbagai tindakan buruk lainnya yang dilakukan dia atau anggota keluarganya. Oleh karena itu, dibutuhkan pengampunan atau belas kasih Tuhan lewat perantaraan dewa laut. Sisi kedosaan ini ditunjukkan dengan adanya lo cu. Lo cu ini bisa berupa seorang pribadi atau sebuah keluarga. Di dalam ritual ini, dia atau mereka selalu berlutut ketika berada di hadapan dewa laut atau ketika mereka berdoa untuk memohon ampun kepada dewa tertinggi. Posisi berlutut ini menjadi simbol dari penyesalan yang mendalam atas segala dosa dan kesalahan yang telah dia atau mereka perbuat. Sehingga, keselamatan yang diartikan mengalirnya rejeki secara terus-menerus senantiasa dicurahkan kepadanya atau keluarga tersebut.

Dosa dalam konteks ritual ini juga diartikan sebagai tidak terlaksananya berbagai aturan atau hukum yang ada berkaitan dengan pelaksanaan ritual tersebut. Sudah sejak persiapan ritual ini, masing-masing pribadi yang terlibat di dalamnya selalu menjalankan persiapannya dengan penuh kehati-hatian. Salah satu contohnya adalah ritual bertanya kepada dewa dapur mengenai bentuk dan ukuran yang dikehendaki. Jawaban yang diberikan oleh dewa dapur menjadi hukum, ketetapan atau aturan yang harus dijalankan. Pelanggaran terhadap aturan ini akan membawa kemalangan bagi banyak orang, terutama masyarakat Tionghoa yang berada di Bagansiapiapi. Bila direfleksikan hal ini sebenarnya senada dengan paham dosa yang ada di dalam Kitab Suci, yaitu bahwa dosa juga diartikan sebagai pelanggaran terhadap hukum atau aturan yang dianggap suci. Selain bertanya kepada dewa dapur, masih banyak ritualritual lainnya yang perlu untuk dijalankan demi keselarasan dan kedamaian. Ritual pemanggilan lima dewa penjaga tentunya juga merupakan bagian dari aturan (suci) yang harus dijalankan. Tarian-tarian para tiong hia juga menjadi, dalam arti ini, bagian dari aturan atau hukum tersebut. Kesetiaan pada hukum dan aturan (suci) akan mendatangkan keselamatan, sedangkan pelanggaran terhadapnya akan mengakibatkan yang sebaliknya, yaitu kemalangan.

Bagi orang Tionghoa sendiri, penghormatan terhadap orang tua dan para leluhur adalah salah satu hal yang penting. Penghormatan terhadap orang tua dan leluhur 
dapat dilakukan dengan tetap melakukan apa yang menjadi tradisi dan budaya mereka. Ritual bakar tongkang adalah salah satu ritual yang terus-menerus dipelihara dan dilakukan dari generasi ke generasi. Ritual ini menjadi ritual wajib bagi mereka karena berkaitan erat dengan keselamatan. Maka, melakukan ritual ini adalah mendatangkan keselamatan bagi mereka, sedangkan kealphaan dalam melakukannya akan mendatangkan kemalangan. Inilah yang dihindari oleh warga etnis Tionghoa di Bagansiapiapi, yaitu datangnya kemalangan. Dalam pengertian ini, kealphaan dalam melakukan ritual dapat diartikan sebagai dosa karena mereka tidak setia dan tidak menaruh hormat kepada para leluhurnya. Padahal dalam keyakinan mereka, para leluhur mempunyai peran yang cukup penting dalam mendatangkan keselamatan - berupa kedamaian, rejeki, berkat - bagi keturunanketurunan mereka. Ketidaksetiaan terhadap ritual dan penghormatan leluhur merupakan pra syarat hadirnya keselamatan atas diri keluarga dan masyarakat.

Dari pembahasan di atas cukup jelaslah bahwa ada kesadaran akan sisi kedosaan yang begitu nampak dalam upacara ritual ini. Mereka meyakini dan percaya bahwa dosa menjadi penghambat sampainya rahmat keselamatan ke dalam diri mereka. Dosa menjadi salah satu sumber tidak harmonisnya hubungan antara manusia dengan sesama manusia, alam ciptaan dan juga Tuhan. Maka, dewa laut yang sebagai perwakilan dewa tertinggi juga membantu memohonkan kepada dewa tertinggi pengampunan kepada mereka yang pada saat upacara itu menyadari dan mengakui segala kedosaan mereka. Memang, dalam konteks ritual ini, keselamatan masih dihayati sebagai keselamatan duniawi. Artinya, bahwa keselamatan di sini berhubungan dengan datangnya rejeki. Dosa dimaknai sebagai penghalang rejeki ini datang ke dalam diri mereka. Dosa menyebabkan aliran rejeki itu tersumbat. Hanya dengan rahmat belas kasih dari Tuhan, mereka mendapatkan kembali rahmat itu. Maka, dalam ritual ini benar-benar sudah dinampakkan sisi manusia yang terkadang - dan mungkin juga selalu - hidup di dalam kuasa dosa.

\section{Tawaran Keselamatan yang Tidak Pernah Berhenti}

Ritual bakar tongkang di Bagansiapiapi merupakan kegiatan tahunan di kota tersebut. Ritual ini menjadi pula kesempatan bagi mereka yang berasal dari Bagansiapiapi untuk kembali lagi ke kota tersebut sebagai bentuk tilik omah dan bertemu dengan sanak saudara. Bagi mereka, ritual ini menjadi kesempatan yang baik untuk menjalin kembali relasi persaudaraan dalam suasana kegembiraan dan harmonis. Dalam suasana tersebut jalinan persaudaraan dirajut kembali dan menjadi sarana bagi mereka untuk saling berbagi; baik itu pengalaman hidup maupun materi. Maka, seperti apa kesibukan mereka dalam keseharian, mereka sudah mempersiapkan segalanya sehingga ketika tiba ritual itu hendak dilakukan mereka dapat kembali ke Bagansiapiapi dan ikut merayakannya bersama keluarga dan sanak-saudara.

Terjalinnya hubungan yang harmonis dan penuh persaudaraan ini merupakan efek lain dari adanya ritual tersebut. Tetapi efek lain tersebut sebenarnya merupakan simbol dari keselamatan duniawi dalam bentuk harmonis dan perdamaian. Terciptanya keharmonisan di dalam keluarga maupun keluarga besar akan membawa efek positif bagi banyak hal. Lancarnya bisnis karena dukungan seluruh anggota keluarga, harmonisnya hubungan antar saudara di dalam 
keluarga maupun pula di dalam masyarakat dan berbagai bentuk lainnya merupakan bagian dari harapan dan cita-cita dari apa yang ingin dibangun pula dalam ritual ini. Tentunya, ketika ada permasalahan di dalam keluarga, kesempatan ini juga menjadi kesempatan yang baik untuk saling mengampuni dan memaafkan.

Oleh karena itu, ritual bakar tongkang ini dapat dimaknai pula sebagai tawaran keselamatan dari Tuhan yang terus-menerus diberikan. Tawaran ini nampak dalam bentuk pengampunan dewa tertinggi atau Tuhan kepada lo cu. Pengampunan menjadi bentuk konkretnya. Pribadi atau keluarga yang disebut lo cu itu mendapatkan belas kasih Tuhan dalam bentuk pengampunan akan segala kesalahan yang telah mereka lakukan selama tahun-tahun sebelumnya. Dengan harapan, dalam pengampunan itu dibukakan kembali rejeki, keharmonisan dalam keluarga dan masyarakat, dan kedamaian. Ritual ini hanya simbol saja dari pengampunan itu dan lo cu juga merupakan simbol pengampunan dari Tuhan kepada siapapun yang memohon ampun dan menyesali segala kesalahannya.

Dalam tradisi Katolik, dosa bukan penghalang Allah dalam memberikan rahmatNya kepada manusia karena Allah itu setia. ${ }^{33} \mathrm{Ke}-$ setiaan Allah tidak pernah dikalahkan oleh dosa - "Allah yang memanggil kamu kepada persekutuan dengan Anak-Nya Yesus Kristus, Tuhan kita, adalah setia" (1Kor 1:9). Meski di dalam diri manusia ada konkupisensi, ${ }^{34}$ tetapi karya keselamatan Allah tidak pernah bisa dibatalkan. ${ }^{35}$ Dengan adanya sifat konkupisensi itu, sangat dimungkinkan manusia kembali lagi ke dalam situasi kedosaan dan menurut surat 2 Petrus dikatakan bahwa "... tetapi terlibat lagi di dalamnya, maka akhirnya keadaan mereka lebih buruk dari pada yang semula."
(2 Petrus 2:20); untuk itu mereka membutuhkan kesediaan untuk dibimbing kepada keutamaan (2 Petrus 1:5-8). ${ }^{36}$ Karena sifat kedosaan inilah, tawaran keselamatan dari pihak Allah tidak pernah berhenti, malahan terus-menerus ditawarkan kepada manusia. Dari pihak manusia sendiri, rahmat dari Allah ini tetap pula diperlukan karena manusia hidup dalam sebuah tegangan untuk selalu hidup dalam roh Allah dan godaan akan kedosaan. Maka di sinilah letak perjuangan manusia untuk mengalahkan kuasa jahat dengan pertolongan rahmat Allah ${ }^{37}$, karena dalam Kristus, Allah mengampuni manusia berdosa (Ef 3:11) dan Allah berkenan untuk menjumpai dan menyapa umatNya serta mengangkat manusia menjadi anak-anakNya (Ef 1:5). Kisah perjuangan ini nampak jelas pula dalam ritual itu, si pendosa (lo cu) memohon rahmat Tuhan agar dijauhkan dari segala gangguan roh jahat yang mungkin sudah dan akan menggoda. Kesediaan diri untuk mau mengakui kesalahan dan memohon ampun kepadaNya merupakan kunci bagaimana manusia kembali kepada Allah. Sikap lo cu yang senantiasa berlutut ketika berdoa - baik di dalam klenteng maupun di luar klenteng - menjadi simbol kemauan manusia untuk kembali lagi kepada Allah. Kesadaran inilah yang perlu dibangun manusia dalam melihat atau memandang belas kasih Allah. Allah tidak pernah berhenti untuk memberikan tawaran keselamatanNya kepada manusia.

Maka, pengampunan melulu belas kasihan dari pihak Allah. Allah tidak pernah membiarkan manusia hidup dalam suasana kedosaan. Allah senantiasa mengajak manusia untuk kembali kepadaNya dan hal itu dilakukannya dengan cuma-cuma. ${ }^{38}$ Allah dengan tangan terbuka senantiasa menanti kedatangan manusia dan menerima situasi kedosaan itu. ${ }^{39}$ Dan - seperti yang dikutip 
oleh Tom Jacobs dari Surat Rasul Paulus kepada Jemaat di Roma - "Oleh kasih karunia, kita dibenarkan dengan cuma-cuma karena penebusan dalam Kristus Yesus (Rom 3:24). ${ }^{40}$ Kehadiran Kristus ke dalam dunia ini ingin mengabarkan bahwa Allah benar-benar serius dalam mengajak manusia untuk bertobat. Allah ingin mencoba mendatangi manusia dan merasakan situasi seperti yang manusia alami dan bahwa Allah ingin mendekati manusia kemudian menawarkan rahmat keselamatan itu. Walaupun sebuah kesadaran perlu dibangun, yaitu meski Allah telah memberikan pengampunan itu, hal ini bukan berarti bahwa dosa itu kemudian lenyap atau hilang; dosa itu tetap ada, tetapi Allah "menerima" keadaan keberdosaan manusia itu seperti Kristus "yang tidak mengenal dosa, oleh Allah dibuat menjadi dosa, karena kita" (2Kor 5:21). ${ }^{41}$

\section{MENANGKAP TANDA KESELAMATAN: SEBUAH KESIMPULAN}

Rahmat keselamatan yang diberikan Allah kepada manusia bersifat cuma-cuma. Artinya, tidak ada keharusan mutlak dari sisi Allah. Rahmat itu diberikan karena melulu belas kasih Allah kepada manusia. Keselamatan yang diberikan ini kemudian ditangkap manusia dengan iman mereka. Pengakuan iman nampak dalam cara penghayatan religius mereka dalam bentuk berbagai tindakan hidup yang selalu menunjukkan kebaikan. Kesadaran dan pengakuan manusia akan kelemahannya menjadi salah satu hal mendasar yang menjadikan iman itu bertumbuh. Iman menjadi salah satu prasyarat diterimanya keselamatan dari Allah itu. Oleh karena itu, manusia dengan disiplin bertekun dalam iman mereka untuk mendapatkan keselamatan; baik itu secara rohani maupun duniawi. Keselamatan ini seperti sebuah situasi atau keadaan yang mana manusia tidak mengalami keterasingan dari Tuhan-nya. ${ }^{42}$ Keselamatan inilah yang menjadi harapan manusia. Keselamatan inilah yang dirindukan oleh manusia. Siapapun pasti ingin memperoleh karunia keselamatan.

Di pihak lain, sisi kedosaan manusia menghambat sampainya keselamatan itu kepada manusia. Arogansi manusia dengan berbagai bentuknya menyebabkannya tetap terkungkung dalam situasi kedosaan itu sehingga hubungan antara manusia dan Allah melemah. Dosa menyebabkan tawaran keselamatan Allah itu tidak sampai kepada manusia. Sebenarnya, manusia menyadari bahwa dirinya rentan terhadap dosa, tetapi di sisi lain terkadang - sepertinya - manusia menjadi "penikmat" dosa. Padahal dosa membuat jarak antara Allah dan manusia semakin jauh. Dosa membuat belas kasih Allah tak berbalas dalam diri manusia. Dengan kata lain, wahyu yang ingin disampaikan oleh Allah tidak ditanggapi dengan iman oleh manusia. Tetapi rahmat keselamatan itu tidak hilang, hanya tidak berdaya apapun untuk manusia. Daya kekuatan itu tidak punya arti apa-apa bagi manusia karena manusia berada pada posisi tidak setia dengan Allah, manusia berada pada posisi yang sedang menjauh dari Allah. Maka, yang dibutuhkan sebenarnya adalah kesetiaan dan ketekunan pada kehendak Allah, sehingga karunia kasih dan keselamatan yang ingin disampaikan berdaya bagi manusia itu sendiri dan kehidupannya.

Situasi inilah yang ingin ditampakkan dalam keseluruhan upacara ritual bakar tongkang di Bagansiapiapi. Kesadaran manusia akan perlunya penyelamat dan kesadaran akan sikap kedosaan manusia ditampakkan dengan begitu jelas. Dewa laut sebagai wakil dari dewa tertinggi atau Tuhan menjadi per- 
antara keselamatan tersebut. Bentuk nyata keselamatan ditampakkan dalam dua hal. Pertama, adanya kesadaran kedosaan manusia. Kesadaran kedosaan adalah bagian tersendiri dari kisah keselamatan. Karena di situlah keselamatan itu pertama-tama akan dimulai di dalam setiap pribadi. Keselamatan itu sudah ada terus-menerus; hanya apakah manusia menyadarinya atau tidak. Maka, dengan kesadaran akan kedosaan dan kemudian berani untuk meminta belas kasih Tuhan, pada tingkat inilah manusia dipantaskan untuk menerima rahmat Allah yang berupa keselamatan itu. Kedua, keselamatan ditampakkan secara aktual dan faktual lewat arah jatuhnya tiang utama kapal tongkang tersebut. Keselamatan di sini dimaknai sebagai keselamatan secara duniawi, yaitu hadirnya rejeki, lancarnya pekerjaan, keberuntungan, harmoni dan dijauhkan dari segala gangguan atau hambatan. Arah jatuhnya tiang utama kapal menjadi penanda arah datangnya rejeki untuk kehidupan mereka satu tahun ke depan. Inilah keselamatan bagi mereka, orang-orang Tionghoa di Bagansiapiapi. Pembersihan diri di dalam ritual itu menjadi penanda agar mereka dipantaskan dan dimampukan untuk menerima keselamatan itu. Di dalam tradisi Katolik, terutama Kitab Suci, keselamatan itu dapat pula dimaknai secara duniawi, yaitu sejahtera dan selamat (Kej 29:6; 43:27), tentram (Mzm 4:9), ramah (Kej 37:4), hubungan baik (Hak 4:17), persahabatan (Yos 9:15). ${ }^{43}$

Maka, ritual bakar tongkang ini merupakan simbol bagaimana usaha manusia untuk menangkap tawaran keselamatan. Dalam tradisi Katolik, usaha ini digambarkan dengan bagaimana manusia memupuk iman mereka lewat penghayatan dan sikap hidup sehari-hari. Konkupisensi atau kecenderungan ke kedosaan memang ti- dak pernah hilang, tetapi manusia karena imannya diberi rahmat oleh Allah untuk mampu berpegang teguh pada keutamaankeutamaan dan dikuatkan ketika godaangodaan itu datang. Dalam konteks ini pula, ritual bakar tongkang menjadi usaha manusia untuk menangkap dan kemudian mendapatkan rahmat keselamatan yang diharapkan. Sehingga, Si lo cu itu dapat kembali bersih dan suci serta dipantaskan untuk menerima keselamatan.

Berhadapan dengan budaya-budaya yang ada, Gereja Katolik senantiasa terbuka karena budaya merupakan "sarana dan upaya manusia untuk menyempurnakan dan mengembangkan pelbagai bakat dan pembawaan jiwa-raganya" (GS art. 53) dan pula "Sebab Allah, yang mewahyukan Diri kepada umat-Nya hingga penampakan Dirinya sepenuhnya dalam Putera-Nya yang menjelma, telah bersabda menurut budaya yang khas bagi pelbagai zaman" (GS art. 58). Maka, menjadi jelaslah bahwa Gereja pun tetap mempunyai rasa hormat kepada kekayaan budaya-budaya yang ada. Dalam konteks Asia, para Uskup Se-Asia pun mengatakan bahwa "Selama Sabda Allah tidak menjadi daging dalam kebudayaan-kebudayaan kita, jiwa Asia tetap akan tidak tersentuh". ${ }^{44} \mathrm{Hal}$ ini semakin menegaskan bahwa apa yang dipunyai oleh budaya dapat pula menjadi kekayaan Gereja dalam pemaknaannya di dunia. Maka dalam kontek tulisan ini, beberapa hal dapat disebutkan. Pertama, bahwa pengharapan akan keselamatan itu menjadi nyata di dalam kehidupan sehari-hari. Ritual bakar tongkang merupakan sebuah ritual yang menyimbolkan bagaimana warga Tionghoa di Bagansiapiapi mencoba untuk menangkap tawaran keselamatan dari Tuhan. Lewat ritual itu pengharapan akan datangnya keselamatan dihadirkan. Jatuhnya tongkang menjadi penanda keselamatan 
(dalam artian duniawi) yang akan dianugerahkan Tuhan kepada manusia untuk tahun berikutnya. Pengharapan ini semakin nyata ketika mereka benar-benar dengan tulus ikhlas bekerja sama untuk mempersiapkan ritual ini dengan sebaik-baiknya. Kedua, keselamatan juga berkaitan dengan kelakuan atau tingkah laku manusia. Dalam ritual ini, sangat ditunjukkan peran manusia di dalam usahanya untuk mendapatkan keselamatan. Mereka mencoba untuk mengikuti aturan-aturan atau hukum-hukum suci yang ada sehingga apa yang mereka lakukan atau apa yang mereka perbuat tidak bertentangan bahkan berkebalikan dengan hukum atau aturan tersebut. Hal ini nampak dalam beberapa peristiwa, yaitu: ketika mereka mencari apa yang dikehendaki oleh dewa dapur berkaitan dengan perayaan ini dan ketika lo cu menyadari akan tindakannya yang buruk dan ingin kembali pada kebaikan. Maka, dalam hal ini keselamatan mempunyai keter-

\section{CATATAN AKHIR}

1 Dr. Nico Syukur Dister, Teologi Sistematika 2 (Yogyakarta: Kanisius, 2004) 122.

Ibid., 129.

INDONESIA.GO.ID, "Suku Bangsa" https://indonesia. go.id/profil/suku-bangsa (diakses 04.06.2019)

4 Badan Pusat Statistik, "Jumlah dan Distribusi Penduduk" https://sp2010.bps.go.id/ (diakses 04.06.2019)

5 Prof. Kong Yuanzhi, Silang Budaya Tiongkok-Indonesia, trans. Xie Zhiqiong-Prof.Kong Yuanzhi-Xie Yinghua (Jakarta: PT Bhuana Ilmu Populer, 2005) 1.

$6 \quad$ Ibid., 26.

Ketika zaman orde baru dikeluarkanlah Instruksi Presiden no. 14 Tahun 1967 yang mengatur tentang pelarangan praktik agama dan budaya Tiongkok di hadapan umum. Tetapi Presiden Abdurrahman Wahid (Gus Dur) melalui Keputusan Presiden no. 6 Tahun 2000 kemudian membatalkan Instruksi Presiden tersebut. Pada tahun 2000 Presiden Gus Dur juga menetapkan Imlek sebagai hari libur opsional. Pada tahun 2003, Presiden Megawati menetapkan Imlek sebagai hari libur nasional. Keputusan Presiden Megawati ini berlaku secara efektif sejak 2 Februari 2003

Eddie Lembong, "Indonesian Government Policies and the Ethnic Chinese: Some Recent Developments," Ethnic Chinese in Contemporary Indonesia, ed. Leo Suryadinata (Singapore: ISEAS Publications, 2008) 52-53.

8 Frans H Winata, "No More Discrimination Against The Chinese," Ethnic Chinese in Contemporary Indonesia, ed. Leo Suryadinata (Singapore: ISEAS Publications, 2008) 64-65.

$9 \quad$ Badan Pusat Statistik Kabupaten Rokan Hilir, Kabupat- kaitan yang cukup erat dengan moral karena dosa sendiri juga dapat diartikan sebagai kelakuan yang menyimpang, kelakuan yang dapat menimbulkan kemalangan bagi dirinya sendiri maupun orang lain. Ketiga, tradisi merupakan hasil usaha manusia dalam mengaktualisasikan dirinya. Maka di dalam tradisi tersebut juga terkandung hubungan atau relasi yang mendalam antara manusia dan Tuhannya. Maka dalam kaitannya dengan ritual ini, perlu dipikirkan sebuah dialog dan katekese yang mendalam tentang makna keselamatan. Hal ini - mungkin - dapat menjadi tantangan Gereja. Karena dengan adanya dialog dan katekese, makna keselamatan akan semakin diperkaya; kisah Allah yang menyelamatkan manusia dan hidup langsung serta berjumpa dengan manusia akan semakin dikenal; dan karya keselamatan Allah akan semakin menjadi harapan yang nyata di dalam kehidupan manusia. Semoga.

en Rokan Hilir dalam Angka 2018 (BPS Kabupaten Rokan Hilir, 2018) 9.

10 Penulis pernah mengadakan wawancara dengan beberapa tokoh masyarakat Tionghoa mengenai informasi ini.

11 Tangki adalah orang yang dipercaya dapat menjadi perantara komunikasi antara dewa dan manusia. Dalam beberapa kasus, mereka juga dapat menyembuhkan penyakit. Tidak semua orang bisa menjadi tangki, hanya mereka yang dipilih saja. Tugas lain dari seorang tangki adalah menghafalkan tata cara berbagai ritual yang ada. Biasanya mereka mempunyai pakaian dan senjata sendiri, sesuai dengan apa yang diinginkan dewa yang merasukinya. Di dalam perayaan-perayaan tertentu mereka akan beratraksi dengan memukul-mukulkan benda tajam ke badannya, berdiri dengan kaki telanjang di atas benda tajam (pedang, kapak) atau menusuk bagian tubuhnya (biasanya daerah sekitar mulut) dengan benda panjang dan tajam yang menyerupai jarum besar.

12 Lo cu adalah seseorang atau keluarga yang ingin membuang segala bentuk kesialan atau sesuatu yang tidak baik. Hanya ada satu lo $c u$ di dalam perayaan ini dan dia atau mereka ditentukan dengan persetujuan dewa. Di dalam ritual biasanya mereka akan selalu berlutut sebagai simbol pertobatan, mohon ampun dan belas kasih dari dewa.

13 Tiong hia adalah sekelompok orang yang membantu para dewa dan biasanya mereka akan menari di depan meja altar. Masing-masing dari mereka akan membawa bendera sebagai simbol dewa yang dihormatinya karena tarian yang mereka lakukan sebenarnya adalah bentuk penghormatan kepada lima dewa penjaga. 
14 Huat so adalah tali yang disusun seperti sebuah cambuk dan terdapat kepala naga di pangkalnya.

15 Tiong hia yang memakai kain kuning berada di tengah karena menyimbolkan dewa Naca, yang memakai kain biru berada di Timur karena menyimbolkan dewa guntur, yang memakai warna merah berada di Selatan karena menyimbolkan dewa angin, yang memakai warna putih berada di Barat karena menyimbolkan dewa perang dan yang berwarna hitam berada di Utara karena menyimbolkan dewa Utara.

16 Sebelumnya kepala singa itu ditutup dengan kain merah yang melambangkan kebahagiaan. Tujuan ditutupnya adalah agar tidak ada makhluk atau roh jahat yang akan merasuki kepala singa tersebut.

17 Penulis menyebutkan di sini para peziarah karena tujuan mereka datang ke kota Bagansiapiapi adalah untuk melihat ritual bakar tongkang dan berdoa. Mereka tidak hanya dari Indonesia saja, tetapi juga dari beberapa negara tetangga seperti Malaysia, Singapura, Tiongkok dan negara lainnya. Kata peziarah di sini ingin memberi penekanan bahwa tujuan mereka datang bukan hanya semata-mata untuk melihat ritual saja, tetapi juga berdoa untuk memohon keselamatan dan keberuntungan.

18 Susanne K Langer, Philosophy In A New Key (New York Mentor Book, 1955) 124.

19 Tom Jacobs, Syalom Salam Selamat (Yogyakarta: Kanisius, 2007) 9 .

20 Dr. Nico Syukur Dister, op. cit., 126.

1 Tom Jacobs, op. cit., 49.

22 Ibid., 49.

\section{DAFTAR RUJUKAN}

Dokumen Konsili Vatikan II. Jakarta: Obor. 1993.

-------. Dokumen Sidang-Sidang Federasi Konferensi-Konferensi Para Uskup Se-Asia 19921995. Jakarta: Dep. Dokpen KWI. 1997.

Badan Pusat Statistik Kabupaten Rokan Hilir. Kabupaten Rokan Hilir dalam Angka 2018. BPS Kabupaten Rokan Hilir. 2018.

Badan Pusat Statistik, "Jumlah dan Distribusi Penduduk" https://sp2010.bps.go.id/ (diakses 04.06.2019).

Callan, Terrance. "The Soteriology of the Second Letter of Peter." Biblica Vol. 82, No. 4 (2001) 549-559.

Dhavamony, Mariasusai. Fenomenologi Agama. Yogyakarta: Kanisius.1995.

Dister, Dr. Nico Syukur. Teologi Sistematika 2. Yogyakarta: Kanisius. 2004.

Groenen, C. Soteriologi Alkitabiah. Yogyakarta: Kanisius. 1989.

INDONESIA.GO.ID, "Suku Bangsa" https://indonesia.go.id/profil/suku-bangsa (diakses 04.06.2019)
$23 \quad$ Ibid., 49

24 Dr. C. Groenen OFM, Soteriologi Alkitabiah Keselamatan yang Diberitakan Alkitab (Yogyakarta: Kanisius, 1989) 89.

$25 \quad$ Ibid., 92.

$26 \quad$ Ibid., 91

Ibid., 91.

Ibid., 93.

Ibid., 95.

Ibid., 96

Ibid., 99.

Ibid., 99 .

Ibid., 58

Dr. Nico Syukur Dister, op. cit., 176.

Tom Jacobs, op. cit., 58.

Terrance Callan, "The Soteriology of the Second Letter of Peter," Biblica Vol. 82, No. 4 (2001) 554.

37 Dr. Nico Syukur Dister, op. cit., 176.

38 Tom Jacobs, op. cit., 61.

$39 \quad$ Ibid., 59.

$40 \quad$ Ibid., 61.

$41 \quad$ Ibid., 59

42 Woodbridge O Johnson, "Non-Christian Salvation," Journal of Bible and Religion Vol. 31, No. 3 (1963) 216.

43 Tom Jacobs, op. cit., 32.

44 Departemen Dokumentasi dan Penerangan Konferensi Waligereja Indonesia, Dokumen Sidang-Sidang Federasi Konferensi-Konferensi Para Uskup Se-Asia 1992-1995 (Jakarta: Dep. Dokpen KWI, 1997) 212.

Jacobs, Tom. Syalom Salam Selamat. Yogyakarta: Kanisius. 2007.

Johnson, Woodbridge O. "Non-Christian Salvation." Journal of Bible and Religion Vol. 31, No. 3 (July 1963) 216-224.

Langer, Susanne K. Philosophy in A New Key. New York: Mentor Book. 1955.

Lembong, Eddie. "Indonesian Government Policies and the Ethnic Chinese: Some Recent Developments." Ethnic Chinese in Contemporary Indonesia. ed. Leo Suryadinata. Singapore: ISEAS Publications (2008).

Winata, Frans H. "No More Discrimination Against the Chinese." Ethnic Chinese in Contemporary Indonesia. ed. Leo Suryadinata. Singapore: ISEAS Publications (2008).

Yuanzhi, Prof. Kong. Silang Budaya Tiongkok-Indonesia. trans. Xie Zhiqiong-Prof.Kong Yuanzhi-Xie Yinghua. Jakarta: PT Bhuana Ilmu Populer, 2005. 